\title{
Research on Development Strategy of Double-Qualified Teachers in English Education
}

\author{
XU Daoping ${ }^{1, b}$, ZHAO Weihong ${ }^{1, a}$, CUI Guiying ${ }^{1, c}$ \\ ${ }^{1}$ Qingdao Huanghai College, China

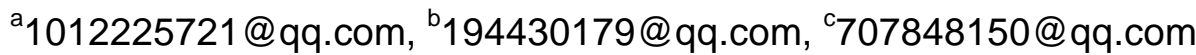

\begin{abstract}
Keywords: Double-Qualified Teachers; Dimension; Action learning theory; English teaching
\end{abstract} Abstract. Based on the knowledge and practice ability of double-qualified English teachers, the systematic analysis of English teaching is carried out. Using action learning theory as the theoretical fulcrum to explain the basic idea of action learning theory which provides theoretical support for the development of double-qualified teacher's teaching ability. The development strategy of response is put forward based on the analysis of the current English teaching problems.

\section{Introduction}

Undergraduate English education is closely related to the development of economic and social culture. With the rise of economic, social and cultural development and popularization of higher education internationalization in China, undergraduate English education has become a typical category in our country's higher education system and has attracted more and more attention in the field of education theory and practice. At present, the development of double-qualified English teacher's teaching ability that matching the training objectives and educational ideas of English education has the characteristics of restriction, orientation and decisive and it have turned into the focus, difficulty and focus of the reform and development in undergraduate colleges and universities [1]. Most undergraduate courses of double-qualified teacher's overall teaching ability in Chinese universities and colleges are at a middle level, its promotion and development space is huge. With the necessity, importance and urgency, the current situation of the development of the "double qualified" teachers' teaching ability need systematically study and change.

\section{The characteristics of "double-qualified teachers"}

The Definition and Connotation. The double-qualified teachers in colleges and universities has higher connotation than the secondary vocational schools, which can not only teach the professional knowledge, but also can carry out professional practice, they both have lecturers or above title, and obtain the national unified examination of the professional intermediate title. It is not difficult to deduce the genetic, environment, practice and personality are four factors affecting the development of people's ability based on two levels of factors in education, among them, the genetic is its physical condition, practice is the basic method, and environment and personality are its important components. Of the four chief elements and apart from heredity as the material foundation or premise that is relatively stable, environment, practical activities and personal qualities are not in a change which can promote the development of the ability [2].

With the understanding of the connotation and extension on the deepening and expanding of the concept of teaching, the content and form of teaching are in movement which makes the teaching ability of the "double-qualified teachers" in colleges and universities dynamically. It is the dynamic nature that makes it possible to develop double-qualified teacher's teaching ability.

Teachers' Practical Ability. Teachers' practical ability can't be abstracted and always with a certain activity as its carrier to reflect. As to the teaching ability of double-qualified English teachers in colleges and universities, if the teacher leaves the teaching practice, their teaching ability will not be reflected, teaching ability developed and elevated along with the teaching practice. Practice determines the teaching ability of teachers, it is necessary to use the teaching practice to display, develop and 
promote the teaching ability which is difficult to be realized only at the theoretical level. At the same time, the basic subject of practice is the person and the person has the subjective initiative in the practice activity. Therefore, the development of turnover teachers' teaching ability needs the subjective efforts which are the practical embodiment and vivid expression [3]. That is to say, the practical nature of subjective initiative is in the practice of teachers' teaching ability.

\section{Discussion on the system of teaching}

Content Composition. From different perspectives or dimensions, education can be divided into different categories or levels. Teaching ability can be divided into imitation ability and creative ability based on the creative size or cognitive ability, Meta cognitive ability, operating ability and social ability according to the dimensions of cognitive objects. According to the trend of development in life and the multi-dimensional nature, it also can be divided into fluid capacity and crystal ability, etc. These abilities are interrelated, mutual influence, mutual integration, and with teachers, teaching and other concepts of understanding or definition of diversity, education has the characteristics of the system.

Action learning theory. With the completion of scheduled work for the purpose, solving the problem as the core, action learning is mainly directed to the teaching of education and based on their own experience, through the reflection and questioning of the experience, it is known that practice action is the theoretical system to promote the common development of individuals and organizations. According to the theory of action learning, learning is not a process of communication and reception of knowledge in a general sense, but rather a process of purposeful, conscious, reflective, collaborative, active and active practice. Action learning is based on reflection and action. Learn from the experience, reflect in learning, comprehend in reflection, action in understanding, learning in action, enhance and develop in learning. Action learning theory emphasizes the combination of experience, peer support and action to solve practical problems. From the learning process and effect, action learning is not only a kind of ideal learning method, but also an effective learning strategy. Compared with other learning theory, while the content of action learning includes learning the professional knowledge, but its main purpose is not obtained this professional knowledge, but uses the skills that acquired to solve practical problems [4].

\section{The Analysis of English teaching problems}

Sense of Weak Scientific Research. The occupational ethics level of college English teacher is generally high, they are dedicate and prepare lesson conscientiously to improve the English level of students. But their sense of scientific research is relatively weak and they often ignore the scientific research work after-school hours. Even some teachers believe that teachers should teaching and educating people, doing research doesn't have practical significance.

Job burnout. College English teachers often have a lot of class, most of them are the repeat class which means a prepared lesson plan can be repeated four or five times. Teachers are more and more familiar with the teaching contents. They feel more and more relaxed. With the monotonous repetition and the lack of challenging lasts, it's easy for teachers to have a job burnout. Once the job burnout appears, it will be very difficult for teachers to innovate in teaching, not to talk about the scientific research [5].

Small Platform of Scientific Research. At present, college English teachers' scientific research platform is too small which shows in two aspects: one is the domestic academic journals in English journals are few, the number of small, high level of English magazines is less and less. One is that there are fewer types of English periodicals in the domestic academic journals, the number is small, the high level of English magazines is less. It is very difficult for college English teachers, especially those in regular colleges to publish a paper in a high level of English. The two is that the provincial education authorities have not provided enough scientific research and teaching research topics for college English teachers. The reality is that it is hard to apply for a college project, not to mention the 
provincial subject. Academic motivation of college English teachers is often hit by the lack of display platform, which hinders the speed and quality of college English teachers' professional development.

Lack of Attention. Attention of education authorities and universities, to a certain degree, can greatly affect the enthusiasm of the professional development of teachers. Nowadays, many colleges and universities, especially the science and engineering colleges, pay less attention to college English, college English class is in a subordinate position, both management and students pay more attention to the professional course of study and pay less attention to English learning. A lot of people think that teach college English is only for the need of examination of four/six and the entrance examination, and didn't recognize the long-term impact of English on their future career development. With the global economic integration, the international exchange and cooperation are becoming more and more closely, more and more students use English to communicate in their work after graduation. In this social context, the level of English will become an important factor that affecting the development of college students in the future occupation.

\section{The development strategy of "double-qualified teachers"}

Construction of Teaching Ability Model. Approaching the issue with a multidimensional and composite view is one of the basic ideas to solve complex problems and examine complex things. According to the foregoing, teachers' teaching ability is a complex problem or thing. With a homogenous way to think about this problem, the structure model of teachers' teaching ability will be simplified and vulgarize which not only can't guide teaching practice, but also easy to cause some understanding of the common error in the cognition of the teaching field. Therefore, it is necessary to treat the teachers' teaching ability and structure model in multi dimension and complex view. For example, in the structure model of teaching ability of primary and secondary school teachers constructed by Shen Jiliang, according to the particularity of the teaching ability, the ability of teaching, the general teaching ability and the teaching ability of the specific subjects are in the same dimension. Teachers need to put forward different requirements to their teaching ability, so that their teaching ability and knowledge structure can meet the standard of "double-qualified teachers" based on different educational level and subject area.

Development of Platform. From the perspective of action learning, a good development platform will be the direction, goal and guarantee of action learning. The promotion and development of double-qualified English teachers' teaching ability can't be separated be separated from the school level, which can provide a good platform for development, the platform is the key to enhance the teachers' ability. Colleges and universities should pay attention to the structure of teachers' team, the reform of personnel distribution and management system, and to strengthen the construction of professional teaching team., the strength of a number of outstanding backbone can be integrated and play a leading role model through the formation of a teaching team. At the same time, teachers in the team can complete the project /goal and get a good learning and bonding through teamwork, the teacher's teaching ability will be greatly developed. Problems that college English teachers' professional growth process is facing, such as the heavy teaching task, time independent and less scientific research atmosphere is not strong and so on requires a high degree of attention, and should take effective measures to improve. For example, the provincial education authorities should try their best to give college English teachers more opportunities to declare their subject, they should provide a greater scientific research platform to support and encourage teachers to go outside to learn and participate in academic exchanges.

Effect of Evaluation Development. A good design of college double-qualified English teachers' teaching ability development evaluation plan mainly lies in the understanding and diagnosis of the current situation and the main problems in the development process of the double-qualified teachers' teaching ability. Quantitative analysis and qualitative analysis are not only the most popular research methods of scientific research, but also a practical means to detect the development of teacher's teaching ability. Quantitative analysis with the more objective is generally available to observe and can 
be measured based on data and facts, while the general qualitative analysis has the characteristics of inductive generalization, conjecture and other features. It is not only to adopt the quantitative analysis based on facts and data, but also to sum up the value judgments with certain subjective tendency to measure the teaching ability and level of double-qualified teachers in colleges and universities. The analysis of the sense of cooperation in the unity and cooperation ability of teachers and the reflective consciousness of the teaching reflection ability, is generally adopted the qualitative analysis methods. The analysis in the aspects of teachers' educational reform and scientific research ability can be carried out by quantitative analysis.

\section{Conclusions}

The specialization of "double-qualified teachers" is the inevitable trend of teacher's growth in twenty-first Century, college English teachers' professional development is the only way to improve the quality of College English teaching and cultivate the compound talents of high quality. This paper analyzes the problems and obstacles of college English teachers' professional development and puts forward the coping strategies. As a key force to improve the English level of all kinds of talents, College English teachers should actively develop their self-reflection and self-guidance. The teachers should strengthen mutual cooperation and actively learn from the teaching and scientific research. Education authorities and universities should also create a good platform for scientific research and financial support for the professional development for college English teachers. With multi-pronged approach and work collectively, the professional development of College English teachers can be ensure.

\section{Acknowledgements}

This work was financially supported by the Shandong five-year scientific planning project: Applied undergraduate colleges and universities of the double-qualified development of foreign language teachers (No. CBW15030).

\section{References}

[1] L.P. XIAO: Journal of The Chinese Society of Education, Vol(2002)No.5,p33-35.

[2] ZH.J. Zhang, X.T. Huang: Psychological Science, Vol(2010) No.24,p50-54.

[3] L.W. Gu: Shanghai Education, Vol(2008)No.1,p26-28.

[4] L.YANG: Jiangsu Foreign Language Teaching and Research, Vol(2010) No.5,p33-35.

[5] Sh.R.Wang, Ch.H.Yao: Chinese Foreign Language, Vol(2013)No.5,p4-10. 